\title{
The Effect of the Instructional Media Based on Lecture Video and Slide Synchronization System on Statistics Learning Achievement
}

\author{
I Gede Partha Sindu ${ }^{1, *}$, and A.A. Gede Yudhi Paramartha ${ }^{2}$ \\ ${ }^{1}$ Informatics Engineering Education, Universitas Pendidikan Ganesha, Singaraja, Bali 81116, \\ Indonesia \\ ${ }^{2}$ Informatics Management, Universitas Pendidikan Ganesha, Singaraja, Bali 81116, Indonesia
}

\begin{abstract}
The purpose of this study was to determine the effect of the use of the instructional media based on lecture video and slide synchronization system on Statistics learning achievement of the students of PTI department . The benefit of this research is to help lecturers in the instructional process $i$ to improve student's learning achievements that lead to better students' learning outcomes. Students can use instructional media which is created from the lecture video and slide synchronization system to support more interactive self-learning activities. Students can conduct learning activities more efficiently and conductively because synchronized lecture video and slide can assist students in the learning process. The population of this research was all students of semester VI (six) majoring in Informatics Engineering Education. The sample of the research was the students of class VI B and VI D of the academic year 2016/2017. The type of research used in this study was quasi-experiment. The research design used was post test only with non equivalent control group design. The result of this research concluded that there was a significant influence in the application of learning media based on lectures video and slide synchronization system on statistics learning result on PTI department.
\end{abstract}

Keywords: video and slide synchronization system, lecture slide and video, statistic learning achievement.

\section{Introduction}

Success in a lecture activity is among other things determined by the instructional media used which is capable of arousing interest in the students to learn so that they can learn effectively. A lecturer has to be able to plan a lecture, to process relevant information into learning material, to translate the program tht has been designed into learning objectives, to present the material through varioius methods and instructional media, and to evaluate learning achievement. So far lecture process generally uses slide presentation, which generaly contains the summary of the material which can take the form of brief

*Corresponding author: partha.sindu@undiksha.ac.id 
defintios of a topic, illustrations, pictures and other learning contents. The students so far in learning through a lecture process have not yet optimally understood the material taught. Based on this problem there is a need for a technological innovation in helping the learning process, one of the innovations is the use of video media. Conventional teaching in the classroom can be recorded in a video format video which then can be viewed again by the students. Lecture video can helpp students in replaying the lecture that has taken place before. The result of a study by Paramartha, Sindu, and Aryanto about the development of lecture video and slide synchronization as a media to support electronics teaching was aimed to help students' learning process in understanding a lecture [1]. The result of this study was that a lecture video and slide presentation in which the system can be used to produce a new electronic instructional media in the form of a lecture video and a slide presentation which are presented side by side on a screen and are sychronized based om transition time of each sup-topic. This instructional media is designed so that it can be accessed through computer, tablet, and smart phone through web browser. In addition, the instructional media which is capable of being produced by this system is made in such a way that it is portable and can be transferred from one gadget to another without internet connection.

Research in video and slide synchronization has only reached the stage of usability testing, i.e., to test an interaction between the user and the system based on effectiveness, efficiency and customer satisfaction in using the system. Thus, it is very important to continue the study by doing an evaluation, i.e., by trying out the system with the students to find out to what extent this system affects the students' learning achievement. The previous study which is related to this study is the study done by Primavera and Suarna, which state that an instruction which uses audio-visual media (video) has the supporting capacity toward learning process of a good category. In addition, audio-visual media (video) has proven to be more effective in enhancing the ability to understand (C2), to apply (C3), and to analyze (C4) [2]. Other works that are related to this study are Iwantara, Sadia and Suma, who state that the use of video youtube media in Science instruction can increase students' learning motivation and concept understanding [3]. The result of the study done by Lestari and Maspiyah showed that there was the effect on the students' learning achievement of video media in the teaching of subcompetence in decorating a stage appearance at SMKN 2 Boyolangu Tulungagung [4].

Based on what has been elaborated above, it is felt that there is a need to investigate further whether the use of an instructional media based on lecture video and slide synchronized system has an effect on the students' learning achievement in a study entitled "The Effect of theeee Instructional Media Based on Lecture Video and Slide Synchronization System on Statistics Learning Achievement of the Students of PTI Department." This study aimed to find out the effect of the instructional media based on lecture video and slide synchronization on Statistics learning achievement of the students of PTI Department.

Media is an intermediary or something that sends a message from the sender to the reciever of the message [5]. Instructional media in general is an aid in the teaching and learning process. Instructional media has a very important function, that is, as the carrier of information and something that prevents obstacles in the learning process, so that information or message from the communicator can reach the communicant effectively and efficiently. The effectiveness of the use of video media as the teaching aid cannot be separated from the demand of the development of technology. The use of video media in teaching can help in giving meaningful experiences to the students in terms of cognitive, affective and psychomotor domains and can overcome the time limitation in the classroom and the teaching process becomes more interesting. The lecture video and slide synchronization system is used to produce an electronic 
instructionjal media in video and slide format that are synchronized based on the transisiton time of every sub-topic. This system can be used by the lecturers to make an interactive electronic instructional media which then can be used by the students to support electronic instruction. The lecture video and slide system which can be used to produce a new electronic instructional media in lecture video and slide presentation format which is presented side by side on a screeen and is syncrhonized. Based on the transition time of each sub-topic [1]. The instructional media is designed to be accessible through computer, tablet, and smart phone through web browser. In addition, the instructionalmedia that can be produced by this system can be made for portable use, in which the instructional media can be transferred from a gadget to another without the aid of internet connection.

Statistics is a study that studies how to plan, collect, analyze, and present data. In brief, statistics is a study which is related to data. The term statistics is different from statistic. Statistics os a study that is related to data, while statistic is data, information, or a result of the application of statistical algorithm to a data. From a collection of data statistics can be used to conclude or describe data; this is called descriptive statistics. Most of the basic concepts of statistics assume the theory of probability. Some statical terms include population, sample, sample unit, and probability.

Learning is a process done by an individual to gain a new change in behavior which is entirely the result of his or her experience in interaction with the environment. Learning achievement shows a change in the individual knowlege structure as the result of learning situation [6]. Learning achievement in declarative knowledge form consists of conceptual knowledge and logical knowledge. In addition, learning achievement can also take the form of procedural skill. The desired learning achievement has to be parallel with the learning objectives. If the learning objectives are in cognitive, affective, and psychomotor domains, then the learning achievement lies in those domains. According to behaviorist perspective, learning is a behavior that makes connection between a stimulus $(\mathrm{S})$ and a response $(\mathrm{R})$, and then the connection is reinforced. The behaviorists believe that learning achievement will be more fully mastered if better if the material is memorized over and over again. According to the cognitive perspective, learning occurs in mind so that a behavior can only be called learning if it reaches understanding. Bloom divided learning achievement into three domains, namely cognitive, affective and psychomotor [7]. The cognitive domain is related to learning objectives that are related to the ability to think. The affactive domain is related to the learing objectives that are related to feeling, emotion, value, and attitude that show aceptance or refusal towards something. He psychomotor domain is related to motor skilll and manipulation of materials and objects

\section{Methods}

The type of research method used in this study was experiment research method. Meanwhile, the experiment design used was quasi-experiment. This method is used in an activity of research which proceed in a condition in which the controling of variables is felt to be difficult if it is done in 24 hours so that a pure experiment is difficult enough to conduct. The research design used was Post Test Only With Non Equivalent Control Group Design. In this design sampling was done by selecting classes which are used as sample at ramdom. This design was selected since during the course of the experiment there was no possibility to change the exisring classess. In terms of procedure, this study followed a pattern as shown in Table 1. 
Table 1. Post Test Only With Non Equivalent Control Group Research Design [8]

\begin{tabular}{|l|c|c|c|}
\hline Experiment & $\mathrm{E}$ & $\mathrm{X}$ & $\mathrm{O}_{1}$ \\
\hline Control & $\mathrm{C}$ & - & $\mathrm{O}_{2}$ \\
\hline
\end{tabular}

Note: E: Experiment Group; C :Control Group ; X : (treatment) Instructional media based on video and slide synchronization system; - : no treatment of the experiment instruction; $\mathrm{O}_{1}$ : Post Test Only/observation of experiment group; $\mathrm{O}_{2}$ : Post Test Only/ observation of control group.

The variables used in this study were as follows.

1. Independent Variable

In this study the independent variable was instructional media based on lecture video and slide synchronization system

2. Dependent Variable

In this study the dependent variable was Statistics learning achievement of the students of PTI Department.

This study was conducted at Jurusan Pendidikan Teknik Informatika, Universitas Pendidikan Ganesha. The population consisted of all of he sixth semester students of Jurusan Pendidikan Teknik Informatika. Since the number of individuals / classes was small, saturated sampling was used, thus all of the population was used as sample. Then based on the result of equality testing it was assumed that the conditions and abilities of the classes that were taken as samples were equal.

In this study the form of cognitive test used was a subjective test of essay items. Before the instrument was used, it was tested to know its level of validity, reliability, index of difficulty of the test items, and index of degree of discrimination of the test itrms. The validity of an essay test can be computed by using Product Moment formula. In this study, the testing of the reliability of the essay test was done by using statistical formula, that is, Alpha Cronbach formula. For a standard test, the items tolerated have the range of reliabilies between 0.31 and 0.70 . The next step was determining index of discrimination to know to what extent a test item can discriminate between high ability testees and low ability testees.

Before doing the hypothesis testing, the data that had been collected were subjected to the prerequisite testing first. This prerequisite testing was done to prove that the data had met the prerequisite of parametric statistical analysis. The prerequisite testing done consisted of normality testing and variance homogeneity testing.

The normality testing was done to determine the step in testing by using parametric or non parametric statistics.

The hypotheses to be tested are :

$\mathrm{H}_{0}=$ Data have a normal distribution.

$\mathrm{H}_{\mathrm{a}}=$ Data do not have a normal distribution.

To test the homogeniety of variance for both groups F-test was used, The hypotheses to be tested are

$\mathrm{H}_{0}$ : There is no difference of variance between control group and experiment group.

$\mathrm{H}_{\mathrm{a}}$ : There is a difference of variance between control group and experiment group.

After testing the homogeneity of variance and the normality of data, then it was continued with hypothesis testing. The hypothesis testing was specified into Null Hypothesis (HO) versus alternative hypothesis (HA). Statistically, the hypotheses can be written as follows.

$\mathrm{H}_{0}$ : that is, there is no signifcant effect in the application of the instructional media based on lecture video and slide syncrhonization system on Statistical learning achievement of the students of Jurusan PTI

$\mathrm{H}_{\mathrm{a}}$ : that is, there is a significant effect in the application of the instructional media based on lecture video and slide synchronization system on Statistical learning achievement of the students of Jurusan PTI 
The study used analysis of mean difference between two groups of scores to test the hypotheses.. If it turns out that the data collected have a normal distribution and are heterogeneous, then t-test at sig. $5 \%$ would be used. The t-tes used was pooled variance. The hypothesis was tested by using t-test with the formula used by Sugiyono as follows [8].

$$
t=\frac{\bar{X}_{1}-\bar{X}_{2}}{\sqrt{\frac{\left(n_{1}-1\right) s_{1}{ }^{2}+\left(n_{2}-1\right) s_{2}{ }^{2}}{n_{1}+n_{2}-2}\left(\frac{1}{n_{1}}+\frac{1}{n_{2}}\right)}}
$$

\section{Results and Discussion}

Before collecting data in the field, the instrument was judged first by two experts who were experts in their field, that is, experts in statistics and instructional media. After the expert judgement, then the instrument was revised and the essay posttest was tried out. Based on the result of the try-out, items whose validity, reliability, index of difficulty, and index of discrimination had been found. There were 5 items which had passed the test and were ready to be distributed to the students after the study ended as posttest items about the students' learning achievement. Based on the whole data of the posttest about the students' learning achievement which had been processed, the average score of learning achievement of the experiment class was found. That is, 67. 5 and that of control class was 49.5 which shows the experiment class group had a higher mean than the mean of learning achievement of the control group. The computation of data to test normality, homogeneity, and hypotesis testing beside using Microsoft Office Excel, the computation also used SPSS Statistics 16, and both produced the results of data processing which were not much different, that is, that the two sample classess were normally distributed and homogeneous.

Table 1 Result of Hypothesis testing by SPSS

\begin{tabular}{|c|c|c|c|c|c|c|c|c|c|c|}
\hline \multicolumn{11}{|c|}{ Independent Samples Test } \\
\hline & & \multicolumn{2}{|c|}{$\begin{array}{l}\text { Levene's Test } \\
\text { for Equality of } \\
\text { Variances }\end{array}$} & \multicolumn{7}{|c|}{ t-test for Equality of Means } \\
\hline & & \multirow[b]{2}{*}{$\mathrm{F}$} & \multirow[b]{2}{*}{ Sig. } & \multirow[b]{2}{*}{$\mathrm{t}$} & \multirow[b]{2}{*}{ df } & \multirow[b]{2}{*}{$\begin{array}{l}\text { Sig. (2- } \\
\text { tailed) }\end{array}$} & \multirow[b]{2}{*}{$\begin{array}{c}\text { Mean } \\
\text { Difference }\end{array}$} & \multirow[b]{2}{*}{$\begin{array}{l}\text { Std. Error } \\
\text { Difference }\end{array}$} & \multicolumn{2}{|c|}{\begin{tabular}{|c|}
$\begin{array}{c}95 \% \text { Confidence Interval } \\
\text { of the Difference }\end{array}$ \\
\end{tabular}} \\
\hline & & & & & & & & & Lower & Upper \\
\hline \multirow[t]{2}{*}{$\mathrm{HB}$} & $\begin{array}{l}\text { Equal } \\
\text { variances } \\
\text { assumed }\end{array}$ & 0.356 & 0.554 & 4.880 & 38 & 0.000 & 18.000 & 3.689 & 10.533 & 25.467 \\
\hline & $\begin{array}{l}\text { Equal } \\
\text { variances } \\
\text { not } \\
\text { assumed }\end{array}$ & & & 4.880 & 37.675 & 0.000 & 18.000 & 3.689 & 10.531 & 25.469 \\
\hline
\end{tabular}


The data of learning achievement of the two classes which had been tested were then used to test the hypothesis using t-test aided by Microsoft Office Excel. Based on the comparison of $t_{\text {obs. }}$ and $t_{\text {.c.v. }}$, the criterion used was if $t_{\text {obs. }}>t_{\text {c.v. }}$ then Ho was rejected and Ha was accepted. From the computation it was found that $\mathrm{t}_{\mathrm{obs}}=4.880$ and $\mathrm{t}_{\text {c.v. }}=1.69$, which means that $t_{\text {obs. }}>t_{\text {c.v. }}(4.880>1.69)$. While the hypothesis testing with the aid of SPSS Statistics 16 showed that $\mathrm{t}_{\text {obs. }}=4.880$ and $\mathrm{t}_{\text {c.v. }}=1.69$, thus, $\mathrm{t}_{\text {obs. }}>\mathrm{t}_{\text {c.v. }}(4.880>$ 1.69). Thus, $\mathrm{H}_{\mathrm{a}}$ was accepted and $\mathrm{H}_{0}$ was rejected. The result of study showed that there was a significant effect on learning achievement, thus, Ho was rejected and $\mathrm{H}_{\mathrm{a}}$ was accepted and it can be concluded that there is a significant effect of the implementation of the instructional media based on the lecture video and slide synchronization on Statistcs learning achievement of the students of Jurusan PTI
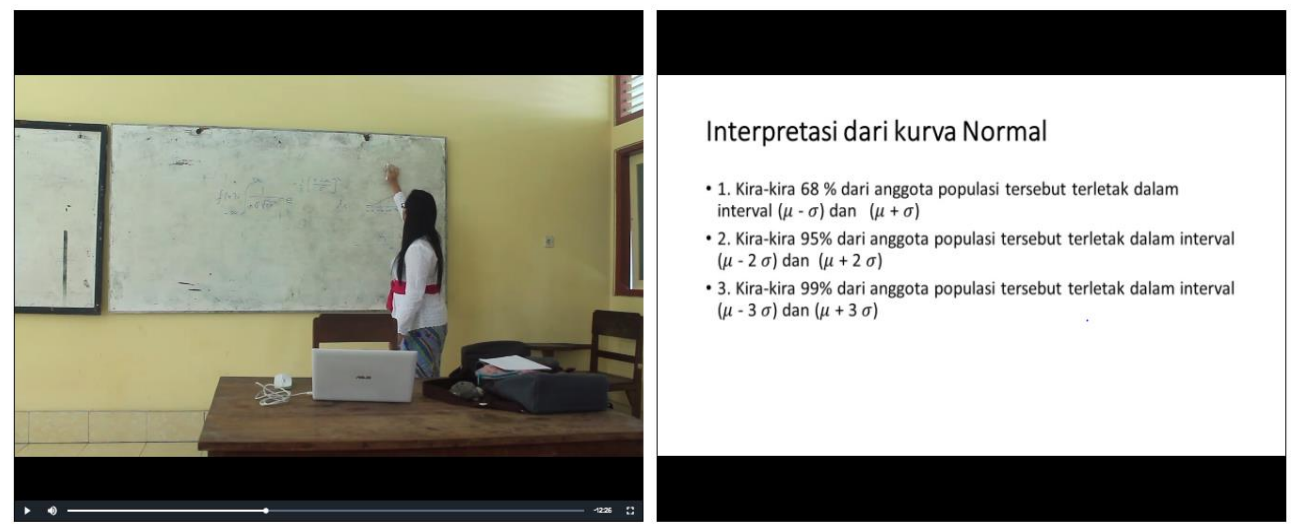

Figure 1. The Display of Video and Slide Syncrhonization System

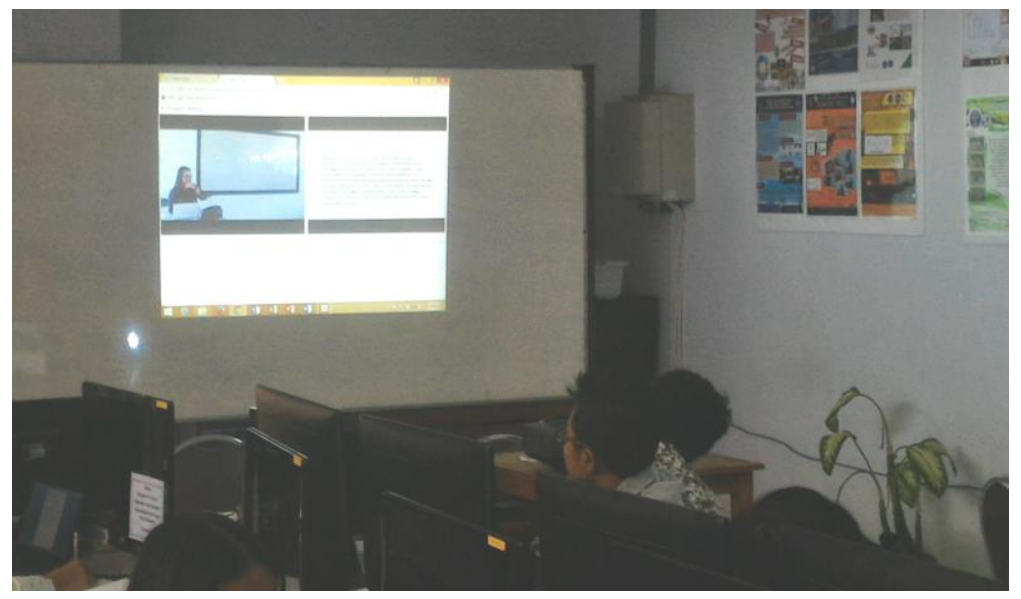

Figrue 2. The Process of Video and Slide Implementation in the Classroom

The instructional media based on video and slide synchronization system gives an added value to the students' progress in learning achievement and increase their motivation to learn. The use of instruction based on video and slide synchronization in the classroom helps very much in the experiment class in understanding the instruction. This result agrees with the result of the study done by Primavera and Suwarna, who state that the instruction that uses audio-visual (video) media has a supporting capacity for the learning process and is categorized into a good category [2]. The result of this study is in 
line with the result of the study entitled "Effects of different video lecture types on sustained attention, emotion, cognitive load, and learning performance," where the effect of video teaching media results in a significant increase in attentionm emotion, and learning achievement of the students [9].The result is also consistent with the result of the study entitled "Learning process and learning outcomes of video podcasts including the instructor and PPT slides, The result revealed that the participants using the video podcast with both the instructor and PPT slides gained the best learning outcomes [10]. Another researh that is related to the instructor's image size in lecture video effect on learning outcomes showed that the students felt the same social presence and cognitive load as in the lecture video with different instructor's size [11]. Based on the theoretical and operational considerations, the implication of this study viewed from constructivist learning theory is the belief in student-centered instruction, in which the student will construct knowledge obtained and modify it to develop new knowledge when he or she is learning, which has an impact on the development of his or her skill and thinking pattern. Thus, the source of the knowledge is an instructional media based on the system of video and lecture slide presentation synchronization.

\section{Conclusions}

On the whole, the finding of the study from the descriptive analysis and hypothesis testing can be concluded that from the descriptive analysis and hypothesis testing the class in which the lecture video and slide synchronization was used gave a better effect compared to the class which was not treated with this media. Theoretically, the use of the instructional media based on video and slide synchronization system facitates the students at the time of learning, that is, at the time of material discussion and it makes the use of instructional time more effective. The constraint in this study lies in the the fact that the lecture video and slide syncrhonization system has not been used optimally in e-learning for the students to access it well. The solution which can be offered to overcomoe this constraint is to optimize the use of e-learning at Universitas Pendidikan Ganesha

\section{Acknowledgments}

The research team would like to extend their gratitude to the Institute of Research and Community of Universitas Pendidikan Ganesha who has supported and approved this research. Our gratitude also goes to the Faculty of Enginnering and Vocations and the Department of Informatics Engineering Education which always support lecturers in doing researchers.

\section{References}

1. A. A. G. Y. Paramartha, I G. P. Sindu, K. Y. E. Aryanto, ICIC. (2016)

2. I. R. C. Primavera, I. P. Suwarna, Prosiding Seminar Nasional Pendidikan IPA FITK UIN Syarif Hidayatullah Jakarta, 122 (2014)

3. I W. Iwantara, I W. Sadia, I K. Suma, E-Journal Program Pascasarjana Universitas Pendidikan Ganesha. 4. (2014)

4. R. C. Lestari, Maspiyah, e-Journal UNESA, 2, 3 (2013)

5. A. S. Sadiman, R. Rahardjo, A. Haryono, Rahardjito. Media Pendidikan; Pengertian, Pengembangan dan Pemanfaatannya, (2002)

6. I W. Santyasa, Buku Ajar Jurusan Pendidikan Fisika. Universitas Pendidikan Ganesha. (2005) 
7. W. N. Nasution, Jurnal Penelitian IAIN, 5 (2006)

8. Sugiyono. Metode Penelitian Kuantitatif Kualitatif dan R\&D, (2013)

9. C. M. Chen, C. H. Wu. Computers \& Education, 80, 108 (2015)

10. Z. Pi, J. Hong. IETI, 53, 135 (2016)

11. Z. Pi, J. Hong, J. Yang. JCAL, 1 (2017) 